\title{
Effects of a prebiotic on growth performance, blood parameters and immunity response of turkeys fed low protein diets
}

\author{
Einfluss des Zusatzes einer Präbiotika-Mischung zu Futterrationen mit niedrigem \\ Rohproteingehalt auf Wachstum, Blutparameter und Immunantwort bei Puten
}

O. Vahabi-Asil', M. Bouyeh', A. Qotbi', I. T. Kadim ${ }^{2}$, A. Seidavi', G. Centoducati ${ }^{3}$, V. Laudadio $^{4}$ and V. Tufarelli $^{4}$

\footnotetext{
1 Department of Animal Science, Rasht Branch, Islamic Azad University, Rasht, Iran

${ }^{2}$ Department of Animal and Veterinary Sciences, College of Agricultural and Marine Sciences, Sultan Qaboos University, Al-Khoud, Muscat, Sultanate of Oman

${ }^{3}$ Department of Soil, Plant and Food, University of Bari 'Aldo Moro', Bari, Italy

${ }^{4}$ Section of Veterinary Science and Animal Production, Department of DETO, University of Bari 'Aldo Moro', Valenzano, Bari, Italy
}

Correspondence: vincenzo.tufarelli@uniba.it

Manuscript received 2 May 2017, accepted 3 June 2017

\section{Introduction}

Restrictions on the use of antibiotics as growth-promoting supplements have resulted in the search of alternative techniques, and the use of prebiotics have received considerable attention because of their health benefits (MUSSATTO and MANCILHA, 2007; BUTEIKIs et al., 2008). The term prebiotics refers to oligosaccharides, which are not digested by the host, and have potential useful effects on host health by selectively stimulating the beneficial microbes that already live there (GIBSON and ROBERFROID, 1995; YANG et al., 2009; ABUDABOS et al., 2015).

According to HOUDIJK et al. (1999), BUTEIKIS et al. (2008) and COSTALOS et al. (2008), prebiotics can play an important role in generating a hind gut microflora that comprises predominantly bifidobacteria in livestock species (BUNESOVA et al., 2014). Digestion of prebiotics by microflora in the colon produces short-chain fatty acids, which reduces $\mathrm{pH}$ in the colon, create unfavourable conditions for development of pathogenic bacteria and facilitates reabsorption of minerals (BUTEIKIS et al., 2008). Turkeys cannot digest lactose due to lack of endogenous lactase, therefore digestive tract bacteria (SIDDONS and COATES, 1972) can digest lactose in diet. The microbial digestion will release fatty acids that are more volatile, lactic acid and microbial proteins (HINTON JR. et al., 1990). Lower pH reduce the number of pathogenic bacteria, more ammonia is used for biosynthesis of microbial proteins and less gets into the blood (Chambers et al., 1997; Simoyi et al., 2006).

Prebiotics are characterised by antimicrobial, anti-carcinogenic, anti-allergic and immunity-stimulation action. They also improve absorption of minerals, protect from diarrhoea and optimise nutrient digestion processes (BUTEIKIS et al., 2008). The impact of prebiotic preparations is the most pronounced when they are used at the beginning of growth, when intestinal microflora is being formed or after such stressful periods as antibiotic treatments and vaccinations. During later stages of bird growth, the positive impact of prebiotic preparations is less pronounced. Results of studies of various combinations of prebiotics have yielded conflicting results (ADEDOKUN et al., 2007, FOYE et al., 2007; AdEDokun et al., 2008; ABDel-AzeEm, 2013; Dinleyicl et al., 2013; AgBoola et al., 2014).

Therefore, the purpose of the present study aimed to investigate the effects of a prebiotics mixture on turkey performance, haematological and immunity response when fed low protein diets. 


\section{Material and Methods}

Animals and dietary treatments

This study was conducted at the farm of the Islamic Azad University, Rasht, Iran. A total of 576 one-day-old male turkeys of Nicholas-300 Commercial strain (Aviagen, Newbridge, Scotland, UK) were used. Prebiotics were obtained from TechnoMos ${ }^{\circledR}$ (Biochem, Lohne, Germany) and containing the same amount of mannan oligosaccharides and beta-glucans from Saccharomices cerevisiae yeast. The trial followed a completely randomised design in a $3 \times 2$ factorial arrangement with three levels of dietary protein: control, $-5.0 \%$ and $-10.0 \% \mathrm{CP}$ reduction (according to the standard catalogue for Nicholas-300 Commercial strain, Aviagen) and two levels of prebiotics mixture (TechnoMos $\left.{ }^{\circledR}\right)$ at 0.0 and $1.0 \mathrm{~g} / \mathrm{kg}$, respectively. Each treatment group was divided into 6 replicates of 16 turkeys per replicate. Treatments/replicate combinations were randomly allocated. The basal diet was the control diet, formulated to meet turkey nutrient requirements, whereas the other 5 diets were considered as experimental treatments. The turkey poults were fed a starter diet from 1 to 28, grower from 29 to 56 and finisher from 57 to 98 day of age, respectively. Birds had ad libitum access to feed and water. The ingredients and chemical composition of the experimental diets fed to turkeys during the different rearing phases are presented in Tables 1, 2 and 3, respectively.

Table 1. Ingredients and chemical composition of the experimental diets for the starter period (1-28 d).

Zusammensetzung und Nährstoffgehalte der Versuchsfutterrationen der Starterphase (1.-28. Lebenstag)

\begin{tabular}{|c|c|c|c|c|c|c|}
\hline \multirow[b]{2}{*}{ Ingredients (g/kg) } & \multicolumn{6}{|c|}{ Diet } \\
\hline & Control (C) & $\begin{array}{l}\mathrm{C}+1 \mathrm{~g} / \mathrm{kg} \\
\text { prebiotic }\end{array}$ & $-5 \% \mathrm{CP}$ & $\begin{array}{c}-5 \% \mathrm{CP}+1 \mathrm{~g} / \mathrm{kg} \\
\text { prebiotic }\end{array}$ & $-10 \% \mathrm{CP}$ & $\begin{array}{c}-10 \% \mathrm{CP}+1 \mathrm{~g} / \mathrm{kg} \\
\text { prebiotic }\end{array}$ \\
\hline Soybean meal & 550 & 550 & 515 & 515 & 515 & 515 \\
\hline Maize grain & 353 & 525 & 394 & 394 & 397 & 396 \\
\hline Vitamin Mineral Premix & 5.0 & 5.0 & 5.0 & 5.0 & 5.0 & 5.0 \\
\hline Choline chloride & 0.4 & 0.4 & 0.4 & 0.4 & 0.4 & 0.4 \\
\hline Prebiotic TechnoMos ${ }^{\circledast}$ & - & 1.0 & - & 1.0 & - & 1.0 \\
\hline Monocalcium phosphate & 26.5 & 26.5 & 26.8 & 26.8 & 28.5 & 28.5 \\
\hline Soybean oil & 34.0 & 34.0 & 27.5 & 27.5 & 24.9 & 24.9 \\
\hline DL-Methionine & 3.8 & 3.8 & 3.6 & 3.6 & 3.2 & 3.2 \\
\hline L-Lysine & 2.9 & 2.9 & 2.8 & 2.8 & 2.7 & 2.7 \\
\hline L-Threonine & 1.1 & 1.1 & 1.0 & 1.0 & 0.9 & 0.9 \\
\hline $\mathrm{NaCl}$ & 1.5 & 1.5 & 1.5 & 1.5 & 1.5 & 1.5 \\
\hline Sodium bicarbonate & 2.4 & 2.4 & 2.4 & 2.4 & 2.4 & 2.4 \\
\hline $\mathrm{CaCO}_{3}$ & 18.0 & 18.0 & 18.2 & 18.2 & 17.7 & 17.7 \\
\hline Vitamin $D_{3}$ & 1.0 & 1.0 & 1.0 & 1.0 & 1.0 & 1.0 \\
\hline \multicolumn{7}{|l|}{ Chemical composition } \\
\hline $\mathrm{ME}(\mathrm{MJ} / \mathrm{kg})$ & 11.4 & 11.4 & 11.4 & 11.4 & 11.4 & 11.4 \\
\hline Crude protein (\%) & 27.6 & 27.6 & 26.3 & 26.3 & 25.1 & 25.1 \\
\hline Crude fibre (\%) & 4.63 & 4.63 & 4.48 & 4.48 & 4.32 & 4.32 \\
\hline Available P (\%) & 0.73 & 0.73 & 0.73 & 0.73 & 0.73 & 0.73 \\
\hline Calcium (\%) & 1.30 & 1.30 & 1.30 & 1.30 & 1.30 & 1.30 \\
\hline Methionine (\%) & 0.72 & 0.72 & 0.69 & 0.69 & 0.64 & 0.64 \\
\hline Lysine (\%) & 1.61 & 1.61 & 1.52 & 1.52 & 1.44 & 1.44 \\
\hline
\end{tabular}


Table 2. Ingredients and chemical composition of the experimental diets for the grower period (29-56 d).

Zusammensetzung und Nährstoffgehalte der Versuchsfutterrationen der Growerphase (29.-56. Lebenstag)

\begin{tabular}{|c|c|c|c|c|c|c|}
\hline \multirow[b]{2}{*}{ Ingredients (g/kg) } & \multicolumn{6}{|c|}{ Diet } \\
\hline & Control (C) & $\begin{array}{l}\mathrm{C}+1 \mathrm{~g} / \mathrm{kg} \\
\text { prebiotic }\end{array}$ & $-5 \% \mathrm{CP}$ & $\begin{array}{c}-5 \% \mathrm{CP}+1 \mathrm{~g} / \mathrm{kg} \\
\text { prebiotic }\end{array}$ & $-10 \% \mathrm{CP}$ & $\begin{array}{c}-10 \% \mathrm{CP}+1 \mathrm{~g} / \mathrm{kg} \\
\text { prebiotic }\end{array}$ \\
\hline Soybean meal & 448 & 448 & 419 & 419 & 395 & 395 \\
\hline Maize grain & 480 & 479 & 512 & 511 & 537 & 536 \\
\hline Vitamin Mineral Premix & 5.0 & 5.0 & 5.0 & 5.0 & 5.0 & 5.0 \\
\hline Choline chloride & 0.3 & 0.3 & 0.3 & 0.3 & 0.3 & 0.3 \\
\hline Prebiotic TechnoMos ${ }^{\circledast}$ & - & 1.0 & - & 1.0 & - & 1.0 \\
\hline Mono-calcium phosphate & 23.0 & 23.0 & 23.3 & 23.3 & 23.5 & 23.5 \\
\hline Soybean oil & 13.0 & 13.0 & 10.0 & 10.0 & 10.0 & 10.0 \\
\hline DL-Methionine & 3.6 & 3.6 & 3.3 & 3.3 & 3.0 & 3.0 \\
\hline L-Lysine & 2.55 & 2.55 & 2.70 & 2.70 & 2.30 & 2.30 \\
\hline L-Threonine & 0.7 & 0.7 & 0.7 & 0.7 & 0.6 & 0.6 \\
\hline $\mathrm{NaCl}$ & 2.0 & 2.0 & 2.0 & 2.0 & 2.0 & 2.0 \\
\hline Sodium bicarbonate & 3.0 & 3.0 & 3.0 & 3.0 & 3.0 & 3.0 \\
\hline $\mathrm{CaCO}_{3}$ & 17.5 & 17.5 & 17.5 & 17.5 & 17.6 & 17.6 \\
\hline Vitamin $D_{3}$ & 1.0 & 1.0 & 1.0 & 1.0 & 1.0 & 1.0 \\
\hline \multicolumn{7}{|l|}{ Chemical composition } \\
\hline $\mathrm{ME}(\mathrm{MJ} / \mathrm{kg})$ & 11.4 & 11.4 & 11.4 & 11.4 & 11.4 & 11.4 \\
\hline Crude protein (\%) & 24.0 & 24.0 & 22.9 & 22.9 & 21.9 & 21.9 \\
\hline Crude fibre (\%) & 4.19 & 4.19 & 4.50 & 4.50 & 3.92 & 3.92 \\
\hline Available P (\%) & 0.64 & 0.64 & 0.64 & 0.64 & 0.60 & 0.60 \\
\hline Calcium (\%) & 1.19 & 1.19 & 1.19 & 1.19 & 1.19 & 1.19 \\
\hline Methionine (\%) & 0.63 & 0.63 & 0.62 & 0.62 & 0.58 & 0.58 \\
\hline Lysine (\%) & 1.32 & 1.32 & 1.31 & 1.31 & 1.23 & 1.23 \\
\hline
\end{tabular}


Table 3. Ingredients and chemical composition of the experimental diets for the finisher period (57-98 d).

Zusammensetzung und Nährstoffgehalte der Versuchsfutterrationen der Finisherphase (57.-98. Lebenstag)

\begin{tabular}{|c|c|c|c|c|c|c|}
\hline \multirow[b]{2}{*}{ Ingredients (g/kg) } & \multicolumn{6}{|c|}{ Diet } \\
\hline & Control (C) & $\begin{array}{l}\mathrm{C}+1 \mathrm{~g} / \mathrm{kg} \\
\text { prebiotic }\end{array}$ & $-5 \% \mathrm{CP}$ & $\begin{array}{c}-5 \% \mathrm{CP}+1 \mathrm{~g} / \mathrm{kg} \\
\text { prebiotic }\end{array}$ & $-10 \% \mathrm{CP}$ & $\begin{array}{c}-10 \% \mathrm{CP}+1 \mathrm{~g} / \mathrm{kg} \\
\text { prebiotic }\end{array}$ \\
\hline Soybean meal & 375 & 375 & 347 & 347 & 322 & 322 \\
\hline Maize grain & 547 & 546 & 580 & 579 & 611 & 610 \\
\hline Vitamin Mineral Premix & 5.0 & 5.0 & 5.0 & 5.0 & 5.0 & 5.0 \\
\hline Choline chloride & 0.25 & 0.25 & 0.25 & 0.25 & 0.25 & 0.25 \\
\hline Prebiotic TechnoMos ${ }^{\circledR}$ & - & 1.0 & - & 1.0 & - & 1.0 \\
\hline Monocalcium phosphate & 21.7 & 21.7 & 22 & 22 & 22.3 & 22.3 \\
\hline Soybean oil & 22.0 & 22.0 & 17.0 & 17.0 & 12.0 & 12.0 \\
\hline DL-Methionine & 3.3 & 3.3 & 3.05 & 3.05 & 2.8 & 2.8 \\
\hline L-Lysine & 2.4 & 2.4 & 2.2 & 2.2 & 2.1 & 2.1 \\
\hline L-Threonine & 0.4 & 0.4 & 0.3 & 0.3 & 0.3 & 0.3 \\
\hline $\mathrm{NaCl}$ & 2.0 & 2.0 & 2.0 & 2.0 & 2.0 & 2.0 \\
\hline Sodium bicarbonate & 2.8 & 2.8 & 2.8 & 2.8 & 2.8 & 2.8 \\
\hline $\mathrm{CaCO}_{3}$ & 16.9 & 16.9 & 17.0 & 17.0 & 17.0 & 17.0 \\
\hline Vitamin $D_{3}$ & 1.0 & 1.0 & 1.0 & 1.0 & 1.0 & 1.0 \\
\hline \multicolumn{7}{|l|}{ Chemical Composition } \\
\hline $\mathrm{ME}(\mathrm{MJ} / \mathrm{kg})$ & 12.0 & 12.0 & 12.0 & 12.0 & 12.0 & 12.0 \\
\hline Crude protein (\%) & 21.2 & 21.2 & 20.2 & 20.2 & 19.4 & 19.4 \\
\hline Crude fibre (\%) & 3.83 & 3.83 & 3.71 & 3.71 & 3.6 & 3.6 \\
\hline Available P(\%) & 0.6 & 0.6 & 0.6 & 0.6 & 0.6 & 0.6 \\
\hline Calcium (\%) & 1.13 & 1.13 & 1.13 & 1.13 & 1.13 & 1.13 \\
\hline Methionine (\%) & 0.61 & 0.61 & 0.57 & 0.57 & 0.54 & 0.54 \\
\hline Lysine (\%) & 1.19 & 1.18 & 1.12 & 1.12 & 1.06 & 1.06 \\
\hline
\end{tabular}

\section{Birds management and sampling}

A total of 576 turkeys were weighed individually and randomly allocated to 36 floors pens $200 \times 200 \mathrm{~cm}$ and lined with wood shavings with similar initial BW $(65.0 \pm 1.8 \mathrm{~g})$ in each pen. Six experimental diets were randomly allocated to pens, such that there were 6 pens each of 16 birds/diet (96 birds/diet). Birds were housed in an environmentally controlled room at $32^{\circ} \mathrm{C}$ for the first week of age and gradually decreased by $1^{\circ} \mathrm{C}$ per week. Relative humidity was recorded (65-85\%). The light program was $23 \mathrm{~h}$ light and $1 \mathrm{~h}$ darkness (23L: 1D) in the first week of age and afterwards $16 \mathrm{~h}$ light and $8 \mathrm{~h}$ of dark (16L: 8D) throughout the study period. The subjects were vaccinated against Newcastle Disease at 1st, 5th, 9th and 12th day of age and against Avian Influenza at the 1st and 9th day of age.

Growth performance data were weekly recorded from 1 to 98 days of age. Feed intake was determined for each repetition as the difference between the amount of feed supplied and the remaining feed at the end of each experimental period. Body weight (BW) and BW gain were calculated as the difference between the final and initial bird weight within each study period. Feed conversion ratio (FCR) was calculated as the ratio of feed intake and BW gain during each phase of the experimental period. 


\section{Immune function evaluations}

At 7, 35, 63 and 84 days of age, blood samples were collected from the brachial vein and antibody titres against Newcastle Disease Virus were determined in birds through haemagglutination inhibition test according to CUNNINGHAM (1971). At 28 and 42 days of age, turkeys were injected i.v. in the breast muscle with $0.5 \mathrm{ml}$ of mixed solution [ $1 \mathrm{ml}$ of PBS with $10 \mathrm{ml}$ of SRBC (sheep red blood cells)]. Blood samples were collected from each bird at 35 and 49 days of age to quantify anti-SRBC antibody titres. Blood samples were collected by puncturing the vena cava using $6 \mathrm{ml}$ vacuum blood collection tubes with heparin as an anticoagulant and then centrifuged at $10000 \mathrm{rpm}$ $\times 15 \mathrm{~min}$. The obtained serum was pipetted and maintained in $2 \mathrm{ml}$ Eppendorf tubes at $-20^{\circ} \mathrm{C}$. The total immunoglobulin $\mathrm{M}$ (IgM), and $\mathrm{G}(\operatorname{IgG})$ anti-SRBC $(\operatorname{IgT})$ antibody titres were determined using a microhaemagglutination technique as described by YAMAMOTO and GLICK (1982) and DIX and TAYLOR (1996). The antibody data were expressed as the log2 of the reciprocal of the highest dilution giving visible agglutination.

\section{Blood biochemistry analysis}

At 98 days of age, one bird per replicate was randomly selected and blood samples were collected for biochemical analysis using syringes. Blood samples were then transferred into blood collection tubes with $10 \mathrm{mg}$ of the anticoagulant ethylene diamin tetra acetic acid (EDTA, Sigma-Aldrich, St. Louis, MO, USA). Samples were centrifuged at $3000 \mathrm{rpm} \times 20 \mathrm{~min}$. The obtained plasma was pipetted and maintained in $2 \mathrm{ml}$ Eppendorf tubes at $-20^{\circ}$ $\mathrm{C}$ until analyses. Plasma constituent analyses were made based on standard protocols using the Roche Cobas Integra 400 Plus Auto-analyzer (Roche Diagnostics, GmbH, Mannheim, Germany). Uric acid, total protein, triglycerides, low-density lipoprotein (LDL), high-density lipoproteins (HDL) and total cholesterol concentrations were assayed using commercial kits (Teif Azmoon Pars, Co., Tehran, Iran).

\section{Statistical analysis}

Data analysis, to evaluate the effect of prebiotics on performance, blood traits and immune response, was carried out with SPSS (1997) software using a GLM procedure in a $2 \times 3$ factorial arrangement. The pen was considered as experimental unit. Significant differences between means were assessed using the LSD procedure. Data $(\mathrm{X})$ as a ratio between $0-0.5$ or percentages between $0-30$ were transformed into $\mathrm{X} \times 0.5+0.5$. 


\section{Results and Discussion}

Feed intake, live BW and gain, and FCR of the turkeys during the starter period (1-28 d), grower period (29-56 d), finisher period (57-98 d) and whole rearing period (1-98 d) are presented in Table 4. The present results revealed that feed intake was not affected by dietary treatments, while BW gain, live BW and the feed efficiency were significantly $(P<0.001)$ influenced by the protein level of the diets during the finisher and whole period of trial. Moreover, there were no differences in growth performance between turkeys receiving diets with or without prebiotics during the three rearing phases. Turkeys that received diets $-10 \% \mathrm{CP}$ and $-10 \% \mathrm{CP}+1 \mathrm{~g} / \mathrm{kg}$ probiotics had significantly $(P<0.001)$ lower BW gain and FCR than those fed the other dietary treatments. Further, there was no difference in growth traits in turkeys fed the following diets: $\mathrm{C},-5 \% \mathrm{CP}, \mathrm{C}+1 \mathrm{~g} / \mathrm{kg}$ probiotics and $-10 \% \mathrm{CP}$, respectively. There were no significant difference in feed intake considering the whole period (1-98 d), but turkeys fed the control diet with or without prebiotics had significantly $(P<0.001)$ higher BW gain compared to the other treatments. Moreover, in turkeys fed the $-5 \% \mathrm{CP}$ diet had significantly higher BW gain than those on diets at $-10 \%$ $\mathrm{CP}$. These results indicate that when protein in the diet was reduced by 5 or $10 \%$, with or without prebiotics, BW gain was significantly $(P<0.001)$ reduced. A similar pattern was found in FCR. The improvement in live BW and gain as well as FCR through the finisher period (57-98 day) might be due to a better digestibility of nutrients (SAHANE, 2001; PELICIA et al., 2004). Thus, the inclusion of prebiotics in diet did not affect the growth performance of turkeys. This is in agreement with research in which it was found that BW and gain in birds were not affected by the supplementation of prebiotics (HoudiJK et al., 1999; Sims and SEFTON, 1999; WALDROup et al., 2003; MidiliI et al., 2008). Similar results for prebiotics on turkey performance were reported by BUTEIKIS et al. (2008). Moreover, PIRAY et al. (2007) demonstrated significant increases in BW gain in broilers receiving diets supplemented with prebiotics. Improvement in feed intake by dietary prebiotics supplementation often results in improved growth performance. However, in a series of feeding trials prebiotics were shown to increase feed intake in poultry (SANCHEZ and AYAYA, 1998). PodmaniczKY et al. (2006), Rosen (2007) and more recently ABUDABos et al. (2015) also reported that prebiotics can improve performance. In contrast to the current study, HOOGE (2003) studied the effects of a prebiotic (mannanoligosaccharides) from 24 trials and concluded that FCR improved by $2.27 \%$. According to ZIMMERMANN et al. (2001), oligosaccharides contribute to an increased absorptive surface of the intestines. In the current study, prebiotic did not have a positive effect on turkey performance, which may be due to low dosage. 
Table 4. Effect of dietary prebiotic and protein levels on growth performance of turkeys during the different rearing periods.

Einfluss des Präbiotika-Zusatzes und des Rohproteingehaltes im Futter auf die Leistung der Puten in den verschiedenen Mastperioden

\begin{tabular}{|c|c|c|c|c|c|c|c|c|c|c|}
\hline & \multicolumn{3}{|c|}{ Prebiotic $(0.0 \mathrm{~g} / \mathrm{kg})$} & \multicolumn{3}{|c|}{ Prebiotic $(1.0 \mathrm{~g} / \mathrm{kg})$} & \multirow[b]{3}{*}{ SEM } & \multirow{2}{*}{\multicolumn{3}{|c|}{$P$-value }} \\
\hline & \multicolumn{3}{|c|}{$\mathrm{CP} \%$} & \multicolumn{3}{|c|}{ CP \% } & & & & \\
\hline & 0 & -5 & -10 & 0 & -5 & -10 & & Protein & Prebiotic & Interaction \\
\hline \multicolumn{11}{|c|}{ 1-28 days } \\
\hline Feed intake (kg/bird) & 1.29 & 1.32 & 1.27 & 1.53 & 1.28 & 1.30 & 0.026 & 0.41 & 0.56 & 0.16 \\
\hline BW gain (kg/bird) & 0.83 & 0.79 & 0.82 & 0.85 & 0.84 & 0.81 & 0.035 & 0.87 & 0.43 & 0.63 \\
\hline FCR & 1.60 & 1.69 & 1.56 & 1.61 & 1.54 & 1.62 & 0.059 & 0.90 & 0.58 & 0.18 \\
\hline Live BW (kg) & 0.878 & 0.852 & 0.888 & 0.912 & 0.903 & 0.873 & 0.036 & 0.89 & 0.44 & 0.71 \\
\hline \multicolumn{11}{|c|}{ 29-56 days } \\
\hline Feed intake (kg/bird) & 5.40 & 5.37 & 5.32 & 5.31 & 5.36 & 5.60 & 0.114 & 0.64 & 0.52 & 0.24 \\
\hline BW gain (kg/bird) & 2.85 & 2.59 & 2.90 & 2.77 & 2.84 & 2.82 & 0.058 & 0.57 & 0.18 & 0.95 \\
\hline FCR & 1.90 & 1.86 & 1.84 & 1.92 & 1.89 & 1.99 & 0.043 & 0.61 & 0.08 & 0.24 \\
\hline Live BW (kg) & 3.73 & 3.74 & 3.79 & 3.68 & 3.74 & 3.69 & 0.054 & 0.61 & 0.56 & 0.82 \\
\hline \multicolumn{11}{|c|}{ 57-98 days } \\
\hline Feed intake $(\mathrm{kg} / \mathrm{bird})$ & 18.8 & 18.9 & 18.8 & 18.9 & 19.0 & 18.93 & 0.213 & 0.97 & 0.60 & 0.99 \\
\hline BW gain (kg/bird) & $6.82^{\mathrm{a}}$ & $6.81^{\mathrm{a}}$ & $6.35^{\mathrm{b}}$ & $6.78^{\mathrm{a}}$ & $6.76^{\mathrm{a}}$ & $6.45^{\mathrm{b}}$ & 0.101 & $<0.01$ & 0.98 & 0.71 \\
\hline FCR & $2.76^{\mathrm{b}}$ & $2.77^{\mathrm{b}}$ & $2.97^{\mathrm{a}}$ & $2.79^{b}$ & $2.81^{\mathrm{b}}$ & $2.94^{\mathrm{a}}$ & 0.040 & $<0.01$ & 0.73 & 0.71 \\
\hline Live BW (kg) & $10.6^{\mathrm{a}}$ & $10.6^{\mathrm{a}}$ & $10.1^{b}$ & $10.5^{\mathrm{a}}$ & $10.5^{\mathrm{a}}$ & $10.1^{\mathrm{b}}$ & 0.112 & $<0.01$ & 0.87 & 0.65 \\
\hline \multicolumn{11}{|c|}{ 1-98 days } \\
\hline Feed intake (kg/bird) & 25.4 & 25.5 & 25.2 & 25.5 & 25.5 & 25.6 & 0.26 & 0.93 & 0.45 & 0.73 \\
\hline BW gain (kg/bird) & $10.4^{\mathrm{a}}$ & $9.41^{b}$ & $8.75^{\mathrm{c}}$ & $10.3^{\mathrm{a}}$ & $9.49^{b}$ & $8.72^{\mathrm{c}}$ & 0.12 & $<0.01$ & 0.92 & 0.72 \\
\hline FCR & $2.44^{\mathrm{b}}$ & $2.45^{\mathrm{b}}$ & $2.53^{\mathrm{a}}$ & $2.47^{\mathrm{b}}$ & $2.46^{\mathrm{b}}$ & $2.58^{\mathrm{a}}$ & 0.04 & 0.02 & 0.25 & 0.87 \\
\hline
\end{tabular}

Means within each row with no common superscript differ significantly at $P<0.05$

SEM: standard error of means; CP: crude protein; BW: body weight; FCR: feed conversion ratio.

It is clear from the available literature that poultry responses to prebiotics supplementation are inconsistent. This may be due to the fact that additives can be effective under particular stress conditions, presence of unfavourable organisms, extreme ambient temperature, diseases, crowding and poor management. Moreover, the beneficial influence of TechnoMos ${ }^{\circledast}$ prebiotic on growth requires more time to alter the intestinal microflora. Turkey gut microbiota plays a key-role in host health, and the establishment of a normal gut microflora could be regarded as complementary to the establishment of digestive enzymes. In commercial poultry production one or more of these conditions are invariably present. Moreover, variations in response to prebiotic supplementation in birds may be due to differences related to strain, hybrid, age, sex, plane of nutrition, nutrient composition of diet, gastrointestinal microbial population, level of inclusion of prebiotics, duration of supplementation or other environmental conditions.

The blood biochemical parameters of turkeys fed the different dietary treatments are presented in Table 5 . There were no differences between the treatment groups for blood constituents, except for uric acid being significantly $(P<0.001)$ higher in serum from the control diet compared to the group fed $-10 \% \mathrm{CP}$ supplemented with prebiotics. In contrast, REKIEL et al. (2007) reported that the prebiotics in a pig diet significantly lowered the concentration of HDL and increased ALT content in blood serum compared to control animals. The current study indicated that the uric acid concentration was affected only by the level of protein in the diet. 
Table 5. Effect of the dietary treatments on blood constituents of turkeys.

Einfluss der Behandlungen auf die Blutkennwerte der Puten

\begin{tabular}{|c|c|c|c|c|c|c|c|c|c|c|}
\hline \multirow[b]{3}{*}{ Item } & \multicolumn{3}{|c|}{ Prebiotic $(0.0 \mathrm{~g} / \mathrm{kg})$} & \multicolumn{3}{|c|}{ Prebiotic $(1.0 \mathrm{~g} / \mathrm{kg})$} & \multirow[b]{3}{*}{ SEM } & \multirow{2}{*}{\multicolumn{3}{|c|}{$P$-value }} \\
\hline & \multicolumn{3}{|c|}{$\mathrm{CP}(\%)$} & \multicolumn{3}{|c|}{$\mathrm{CP}(\%)$} & & & & \\
\hline & 0 & -5 & -10 & 0 & -5 & -10 & & Protein & Prebiotic & Interaction \\
\hline Glucose (mg/dl) & 264 & 253 & 253 & 265 & 258 & 267 & 7.1 & 0.47 & 0.24 & 0.64 \\
\hline Uric acid (g/dl) & $2.11^{\mathrm{a}}$ & $1.87^{\mathrm{ab}}$ & $1.60^{\mathrm{ab}}$ & $1.92^{\mathrm{ab}}$ & $1.65^{\mathrm{ab}}$ & $1.35^{\mathrm{b}}$ & 0.16 & $<0.01$ & 0.11 & 0.98 \\
\hline Total cholesterol (mg/dl) & 129 & 137 & 139 & 126 & 129 & 135 & 6.0 & 0.30 & 0.33 & 0.93 \\
\hline Triglycerides (mg/dl) & 113 & 103 & 108 & 127 & 112 & 135 & 11.2 & 0.38 & 0.07 & 0.71 \\
\hline $\operatorname{VLDL}(\mathrm{mg} / \mathrm{dl})$ & 22.7 & 20.7 & 21.7 & 25.3 & 21.0 & 27.5 & 2.23 & 0.21 & 0.12 & 0.47 \\
\hline HDL-cholesterol (mg/dl) & 70.0 & 68.7 & 79.3 & 67.8 & 70.3 & 68.7 & 4.38 & 0.46 & 0.31 & 0.37 \\
\hline LDL-cholesterol (mg/dl) & 36.2 & 47.5 & 37.8 & 34.3 & 41.3 & 42.7 & 4.21 & 0.11 & 0.76 & 0.43 \\
\hline Alkaline phosphatase (IU/I) & 2915 & 2984 & 3253 & 3081 & 2966 & 3433 & 193 & 0.12 & 0.49 & 0.85 \\
\hline Total protein $(\mathrm{g} / \mathrm{dl})$ & 3.42 & 3.51 & 3.27 & 3.42 & 3.38 & 3.22 & 0.09 & 0.09 & 0.44 & 0.87 \\
\hline Albumin (g/dl) & 1.75 & 1.73 & 1.72 & 1.75 & 1.73 & 1.75 & 0.06 & 0.95 & 0.85 & 0.95 \\
\hline Globulin (g/dl) & 1.67 & 1.61 & 1.55 & 1.65 & 1.65 & 1.48 & 0.12 & 0.46 & 0.91 & 0.88 \\
\hline
\end{tabular}

Means within each row with no common superscript differ significantly at $P<0.05$

SEM: Standard error of means.

VLDL: Very low density lipoprotein; HDL: High density lipoproteins; LDL: Low density lipoproteins

Serum haemagglutination-inhibition titre is a valid indicator of the immunity in birds; therefore, the effects of prebiotics and protein level on the serum anti-Newcastle Disease haemagglutination-inhibition at various ages are reported in Table 6. With the exception of values at 84 days of age, the serum haemagglutination-inhibition titres did not differ significantly between dietary treatments. At 84 days of age, turkeys in the Control $(6.33),-10 \% \mathrm{CP}$ (6.67), $-\mathrm{C}+1 \mathrm{~g} / \mathrm{kg}$ prebiotics (6.33) and $-10 \% \mathrm{CP}+1 \mathrm{~g} / \mathrm{kg}$ prebiotics (6.17) treatments had significantly higher values than of those fed $-5 \% \mathrm{CP}$ without or with prebiotics, respectively. However, blood serum from treatments having $-5 \%$ CP without or with prebiotics had significantly $(P<0.05)$ lower haemagglutination-inhibition titre than the other treatments. The present study indicated that a low dose $(1.0 \mathrm{~g} / \mathrm{kg})$ of the TechnoMos ${ }^{\circledR}$ was not able to demonstrate an increase in serum haemagglutination-inhibition titre. Notably, the results showed that the haemagglutination-inhibition titres in birds fed on diets having $-5 \% \mathrm{CP}$ with and without prebiotics at day 84 were significantly $(P<0.05)$ lower than for the other diets, suggesting that $-5 \% C P$ could decrease the humoral immunity response in broilers.

Table 6. Anti-Newcastle disease haemagglutination-inhibition titres ( $\left.\log _{10}\right)$ of turkeys as affected by different levels of dietary prebiotic and protein.

Einfluss des Pråbiotika-Zusatzes und des Rohproteingehaltes im Futter auf die Newcastle Disease Titer (log $\left.{ }_{10}\right)$

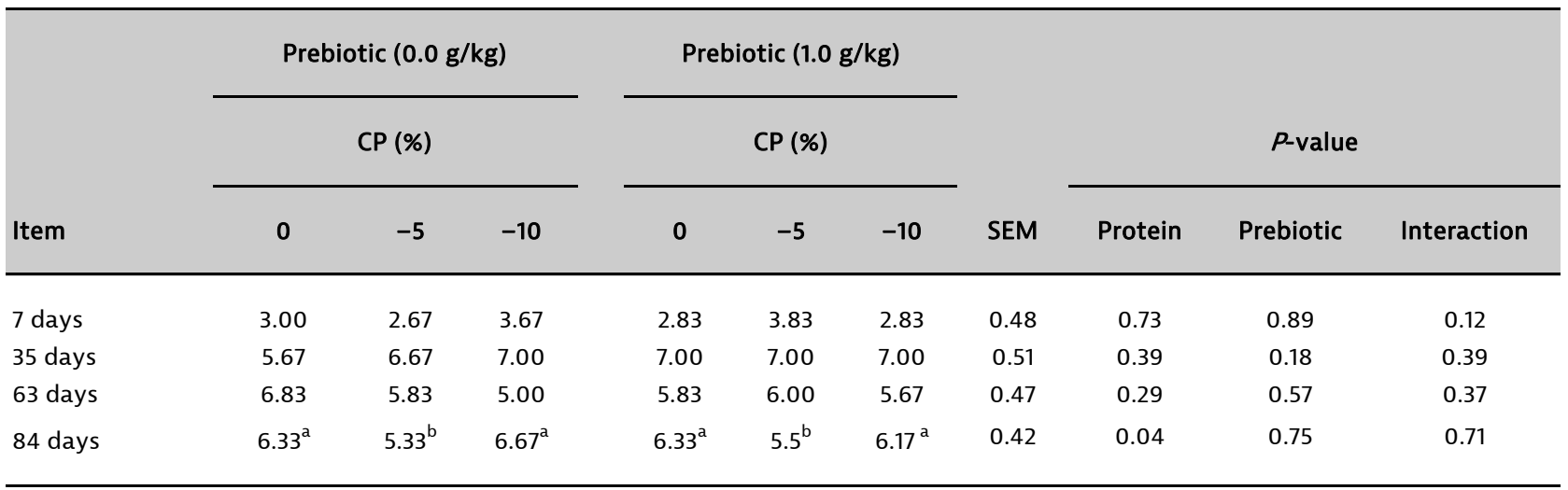

Means within each row with no common superscript differ significantly at $P<0.05$. SEM: Standard error of means. 
The effects of the prebiotic on serum IgT, IgG and IgM concentrations in turkeys are given in Table 7. No significant differences were found in IgT, IgG and IgM concentrations between the control and experimental groups $(P>0.05)$. These results are in agreement with the results of other studies (FRANKLIN et al., 2002). However, the present results differ from the findings of SAVAGE et al. (1996). A possible explanation for the differences in results of different investigators may be related to the doses of prebiotic applied, animal species and study population (e.g. breed, age or weight) as well as composition of the diet. The most important reasons for a positive response is the degree of stress in the animals and/or the unbalanced microbial populations in the digestive tract.

Table 7. Immune response for total sheep red blood cells $(\operatorname{IgT})$, IgG and $\operatorname{lgM}\left(\log _{10}\right)$ values in turkeys as affected by different levels of dietary prebiotic and protein.

Einfluss des Präbiotika-Zusatzes und des Rohproteingehaltes im Futter auf die mittels Schaf-Erythrozyten induzierte Immunantwort (IgT, IgG, IgM; $\log _{10}$ )

\begin{tabular}{|c|c|c|c|c|c|c|c|c|c|c|}
\hline \multirow[b]{3}{*}{ Item } & \multicolumn{3}{|c|}{ Prebiotic $(0.0 \mathrm{~g} / \mathrm{kg})$} & \multicolumn{3}{|c|}{ Prebiotic (1.0 g/kg) } & \multirow[b]{3}{*}{ SEM } & \multirow{2}{*}{\multicolumn{3}{|c|}{$P$-value }} \\
\hline & \multicolumn{3}{|c|}{$\mathrm{CP}(\%)$} & \multicolumn{3}{|c|}{$\mathrm{CP}(\%)$} & & & & \\
\hline & 0 & -5 & -10 & 0 & -5 & -10 & & Protein & Prebiotic & Interaction \\
\hline \multicolumn{11}{|c|}{35 days } \\
\hline $\lg G$ & $2.33^{\mathrm{a}}$ & $1.33^{b}$ & $2.33^{a}$ & $2.33^{a}$ & $1.83^{\mathrm{ab}}$ & $1.17^{\mathrm{b}}$ & 0.31 & 0.05 & 0.38 & 0.03 \\
\hline $\lg M$ & 1.33 & 1.17 & 1.83 & 1.67 & 1.83 & 1.50 & 0.22 & 0.68 & 0.28 & 0.08 \\
\hline $\lg T$ & 3.67 & 2.50 & 4.17 & 4.00 & 3.66 & 2.67 & 0.41 & 0.20 & 0.10 & $<0.01$ \\
\hline \multicolumn{11}{|c|}{49 days } \\
\hline IgG & 5.01 & 4.50 & 4.33 & 4.17 & 4.83 & 5.03 & 0.52 & 0.98 & 0.89 & 0.30 \\
\hline $\lg M$ & $2.33^{\mathrm{ab}}$ & $1.33^{c}$ & $3.04^{\mathrm{a}}$ & $2.17^{\mathrm{abc}}$ & $2.00^{\mathrm{bc}}$ & $2.33^{\mathrm{ab}}$ & 0.29 & $<0.01$ & 0.81 & 0.08 \\
\hline $\lg T$ & 5.00 & 5.67 & 6.02 & 5.67 & 5.00 & 4.17 & 0.58 & 0.43 & 0.64 & 0.01 \\
\hline
\end{tabular}

Means within each row with no common superscript differ significantly at $P<0.05$.

SEM: Standard error of means.

\section{Conclusions}

This study provides evidence that supplementation of prebiotics to turkey diets with different levels of protein did not lead to any significant changes in performance, blood biochemistry and haemagglutination-inhibition titres. Serological data from the present study also showed lack of effectsupplementation on systemic IgG, IgT, and IgM concentrations. Although non-significant results were observed for the examined parameters, further studies are needed to better understand the effects of these additives and to clarify their effect on the immune response of turkeys. The successful use of prebiotics in turkey production will require knowledge of such gut flora-function relationships. Thus, this work could be extended to include the use of different levels of prebiotics in turkey diets.

\section{Acknowledgements}

Financial support by Rasht Branch, Islamic Azad University, grant number 4.5830 is gratefully acknowledged. 


\section{Summary}

The study was conducted to investigate the effects of a prebiotics mixture (mannan oligosaccharides and beta-

glucans; TechnoMos ) on performance, blood biochemistry and immune response of turkeys fed low crude protein (CP) diets. A total of 576 one-day-old male turkeys of Nicholas-300 Commercial strain were divided into 6 dietary treatments as follows: Control $(\mathrm{C})$ basal diet; $\mathrm{C}$ diet supplemented with $1.0 \mathrm{~g} / \mathrm{kg}$ prebiotic; low protein diet having $-5 \% \mathrm{CP}$; low protein $(-5 \% \mathrm{CP})$ diet supplemented with $1.0 \mathrm{~g} / \mathrm{kg}$ prebiotic; low protein diet having $-10 \% \mathrm{CP}$; and low protein $(-10 \% \mathrm{CP})$ diet supplemented with $1.0 \mathrm{~g} / \mathrm{kg}$ prebiotic. Each treatment group was further subdivided into 6 replicates of 16 birds per replicate. Feed intake, feed conversion ratio (FCR) and body weight (BW) gain of birds were recorded in the different growth phases (1-28, 29-56 and 57-98 days of age, respectively). Blood samples were collected from turkeys to determine the effect of protein level and prebiotic on blood biochemistry and immune response.

Dietary prebiotic supplementation did not significantly affect BW and gain, feed intake and FCR, blood traits, haemagglutination inhibition and immunoglobulins (IgT, IgG and IgM). However, dietary protein level had a significant effect on BW gain and FCR during the finisher phase, uric acid concentration at day 98, and IgM titre at day 49. In conclusion, this study provides evidence that supplementing prebiotics in turkey diets with different protein levels did not affect growth performance, blood biochemistry and haemagglutination-inhibition. Dietary protein level had more influence on the examined parameters than prebiotics.

\section{Key words}

Turkey, prebiotics, mannan oligosaccharides, beta-glucans, performance, immune response

\section{Zusammenfassung}

Einfluss des Zusatzes einer Präbiotika-Mischung zu Futterrationen mit niedrigem Rohproteingehalt auf Wachstum, Blutparameter und Immunantwort bei Puten

Das Ziel der Studie war die Untersuchung des Einflusses eines Zusatzes einer Präbiotika-Mischung (MannanOligosaccharide und Beta-Glukane; TechnoMos ${ }^{\oplus}$ zu Niedrig-Protein-Rationen auf die Leistung, die Blutkennwerte und die Immunantwort bei Puten. Hierzu wurden insgesamt 576 männliche Puteneintagsküken der Herkunft Nicholas 300 auf folgende sechs Behandlungsgruppen verteilt: Kontrolle - Basisfutterration, Basisfutterration + $1,0 \mathrm{~g}$ Präbiotikum/kg, Niedrigprotein-Ration I (5\% weniger Rohprotein), Niedrigprotein-Ration I + 1,0 g Präbiotikum $/ \mathrm{kg}$, Niedrigprotein-Ration II ( $10 \%$ weniger Rohprotein), Niedrigprotein-Ration II + $1,0 \mathrm{~g}$ Präbiotikum/kg. Jede Behandlung umfasste sechs Wiederholungen mit je 16 Puten. Futteraufnahme, Futterverwertung (FCR) und Lebendmasse (BW) wurden für die Phasen 1.-28., 29.-56. und 57.-98. Lebenstag erfasst. Die Auswirkungen der Niedrigproteinrationen und des Präbiotkum-Zusatzes auf Blutparameter und Immunantwort wurden bestimmt.

Die Präbiotikum-Zulage hatte keinen signifikanten Einfluss auf das Lebendgewicht, die Lebendmassezunahme, die Futteraufnahme, die Futterverwertung, die Blutparameter, die Blutgerinnung und die Immunglobulin-Titer (IgT, IgG, IgM). Dagegen beeinflusste der Proteingehalt im Futter die Zunahmen und die Futterverwertung in der FinisherPhase, den Gehalt an Harnsäure im Blutserum am 98. Lebenstag sowie den IgM-Titer am 49. Lebenstag signifikant. Die Ergebnisse der Untersuchung deuten darauf hin, dass eine Zulage eines Präbiotikums zu Futterrationen mit unterschiedlichem Proteingehalt kaum Auswirkungen auf die Wachstumsleistung, die Blutparameter und die Blutgerinnung hat, während sich der Proteingehalt selber deutlich auswirkt.

\section{Stichworte}

Pute, Präbiotika, Mannan-Oligosaccharide, Beta-Glukane, Leistung, Immunantwort

\section{References}

ABDEL-AZEEM, M., 2013: Do probiotics affect the behavior of turkey poults? J. Vet. Med. Anim. Health 5, $144-148$. 
Abudabos, A.M., H.A. Al-BATSHAN, M.A. MuRSHED, 2015: Effects of prebiotics and probiotics on the performance and bacterial colonization of broiler chickens. South Afr. J. Anim. Sci. 45, 419-428.

Adedokun, S.A., O. Adeola, C.M. Parsons, M.S. Lilburn, T.J. Applegate, 2008: Standardized ileal amino acid digestibility of plant feedstuffs in broiler chickens and turkey poults using a nitrogen-free or casein diet. Poult. Sci. 87, 2535-2548.

Adedokun, S.A., C.M. Parsons, M.S. Lilburn, O. AdeolA, T.J. Applegate, 2007: Standardized ileal amino acid digestibility of meat and bone meal from different sources in broiler chicks and turkey poults with a nitrogen-free or casein diet. Poult. Sci. 86, 2598-2607.

Agboola, A.F., I. ARoniYo, S. A. SuberU, W.T. AdEYEMI, 2014: Dietary supplementation of probiotics and synbiotics on intestinal microbial populations and gut morphology of turkey poults. Afr. J. Livest. Ext. 14, 13-20.

Bunesova, V., E. VlKova, V. RADA, J. Killer, S. Musilova, 2014: Bifidobacteria from the gastrointestinal tract of animals: differences and similarities. Benef. Microbes 5, 377-388.

Buteikis, G., P. MAtusevicius, A. JanUskevicius, J. JANkowski, D. MikUlski, J. BloK, K. KozIowski, 2008: Use of symbiotic preparations in turkey diets and their effect on growth performance. Vet. Med. Zoot. 16, 14-19.

Chambers, J.R., J.L. Spencer, H.W. ModleR, 1997: The influence of complex carbohydrates on Salmonella typhimurium colonization, $\mathrm{pH}$ and density of broiler ceca. Poult. Sci. 76, 445-451.

Costalos, C., A. KAPIKI, M. Apostolou, E. PAPAThOMA, 2008: The effect of a prebiotic supplemented formula on growth and stool microbiology of term infants. Early Hum. Dev. 84, 45-49.

Cunningham, C.H., 1971: Virologia Practica, 6th Edn. p. 260. Acribia, Zaragoza, Spain.

Dinleyici, E.C., N. DAlgic, S. Guven, M. Ozen, A. KARA, V. ARICA, D. OzTURK, 2013: The effect of a multispecies synbiotic mixture on the duration of diarrhea and length of hospital stay in children with acute diarrhea in Turkey: single blinded randomized study. Europ. J. Pediat. 172, 459-464.

DIX, M.C., R.L. TAYLOR, 1996: Differential antibody responses in 6. B major histocompatibility (B) complex congenic chickens. Poult. Sci. 75, 203-207.

FOYE, O.T., P.R. FERKET, Z. UNI, 2007: The effects of in ovo feeding arginine, $\beta$-hydroxy- $\beta$-methyl-butyrate, and protein on jejunal digestive and absorptive activity in embryonic and neonatal turkey poults. Poult. Sci. 86, 23432349.

FRANKLIN, S.T., K.E. NEWMAN, M.C. NEWMAN, 2002: Evaluation of mannanoligosaccharide on the immune status of dairy cows and their calves. J. Anim. Sci. 80, 192.

GIBSON, G.R., M.B. ROBERFROID, 1995: Dietary modulation of the human colonic microbiota: Introducing the concept of prebiotics. J. Nutr. 125, 1401-1412.

Hinton JR., A., D.E. Corrier, G.E. Spates, J.O. Norman, R.L. Ziprin, R.C. Beir, J.R. De LOACH, 1990: Biological control of Salmonella typhimurium in young chickens. Avian Dis. 34, 626-633.

HOOGE, D.M., 2003: Broiler chicken performance may improve with MOS. Feedstuffs 6, 11-13.

HoudiJK, J.G.M., M.W. Bosch, S. TAmming, W.M.A. Verstegen, E.B. BerenPas, H. KnooP, 1999: Apparent ileal and total-tract nutrient digestion by pigs as affected by dietary non-digestible oligosaccharides. J. Anim. Sci. 77, 148158 ;

Midilli, M., M. AlP, N. Kocabagh, O.H. Muglah, N. TuRAn, H. Yilmaz, S. CAKIR, 2008: Effects of dietary probiotic and prebiotic supplementation on growth performance and serum IgG concentration of broilers. South Afr. J. Anim. Sci. 38, 21-27.

MuSSATTO, S.I., I.M. MANCILHA, 2007: Non-digestible oligosaccharides: a review. Carbohyd. Polym. 68, $587-597$.

Pelicia, K., A.A. Mendes, E.S. SAldanha, C. Piazzolante, S. TAKahashi, 2004: Probiotic and prebiotic utilization in diets for free-range broiler chickens. Br. Poult. Sci. 92, 99-104. 
Piray, A.H., H. KeRmanshahI, A.M. TAHMASBI, J. BAHRAMPOUR, 2007: Effects of cecal cultures and aspergillus meal prebiotic (Fermacto) on growth performance and organ weights of broiler chickens. Int. J. Poult. Sci. 6, 340-344.

Podmaniczky, B.A., Z.S. Kocher, S.B. Vegi, K.H.L. Korosi, A.K. MolnAR, 2006: The effect of mannan oligosaccharides on growth performance of challenged broilers. In: Proceedings of 12th European Poultry Conference, World Poult Sci. J. 62, 319.

ReKiel, A., J. WIECEK, W. Bielecki, J. GAJeWSKA, M. CiCHOWICZ, J. KulisieWiCZ, M. BAtORSKA, T. RoszKOWSKI, K. BEYGA, 2007: Effect of addition of feed antibiotic flavomycin pr prebiotic BIO-MOS on production results of fatteners, blood biochemical parameters, morphometric indices of intestinal and composition of microflora. Arch. Tierz. 50, 172-180.

RoSEN, G.D., 2007: Holo-analysis of the efficacy of Bio-Mos in broiler nutrition. Br. Poult. Sci. 48, 21-26.

SAHANE, M.S., 2001: Mannanoligosaccharides in poultry nutrition: Mechanism and benefits. In Proceedings of Alltech's 17th Annual Symp. Eds. Lyons, T.P. and Jacques, K. A., Nottingham University Press. pp. 65-77.

SANCHEZ, R., J.A. AYAYA, 1998: Effect of MOS on broiler of performance under field conditions. Alltech's INC. 16th July.

SAVAGE, T.F., P.F. COTTER, E.I. ZAKRZEWSKA, 1996: The effect of feeding mannanoligosaccharide on immunoglobulins, plasma IgG and bile IgA of Wrolstad MW male turkeys. Poult. Sci. 75, (Suppl. 1): 143.

SIDDONS, R.C., M.E. COATES, 1972: The influence of intestinal microflora on dissacharidase activities in the chick. Br. J. Nutr. 27, 101-112.

Simoyi, M.F., M. Milimu, R.W. Russell, R.A. Paterson, P.B. Kenney, 2006: Effect of dietary lactose on the productive performance of young turkeys. J. Appl. Poult. Res., 20-27.

SimS, M.D., A.E. SEFTON, 1999: Comparative effects of a mannano oligosaccharide and an antibiotic growth promoter on performance of commercial tom turkeys. In Proceedings of 48th Western Poultry Disease Conf., Vancouver, Canada. 1999; pp. 78-82.

SPSS, 1997: SPSS Base 7.5 for Windows. SPSS, Chicago, IL.

WALDROUP, P.W., C.A. FRITTS, Y. FENGLAND, 2003: Utilization of Bio-Mos ${ }^{\circledR}$ mannan oligosaccharide and Bioplex ${ }^{\circledR}$ copper in broiler diets. Int. J. Poult. Sci. 2, 44-52.

YAMAMOTO, Y., B. GLICK, 1982: A comparison of the immune response between two lines of chickens selected for differences in the weight of the bursa of Fabricius. Poult. Sci. 61, 2129-2132.

YANG, Y., P.A. IJI, M. СHOCT, 2009: Dietary modulation of gut microflora in broiler chickens: A review of the role of six kinds of alternatives to in-feed antibiotics. World Poult. Sci. J. 65, 97-114.

ZIMMERMANN, B., E. BAUER, R. MOSENTHIN, 2001: Pro-and prebiotics in pig nutrition-potential modulators of gut health? J. Anim. Sci. 10, 47-56. 